\title{
Development of Learning Devices through Knisley Mathematical Learning Model to Improve Mathematical Understanding and Disposition Ability of Class VII SMP Swasta Tamora 2
}

\author{
Siti Hanijah Br. Saragih ${ }^{1}$, Edi Syahputra ${ }^{2}$, Syafari $^{2}$, Yuli Ragelia Sinaga ${ }^{3, *}$ \\ ${ }^{1}$ Education of Mathematics Post Graduation, Universitas Negeri Medan \\ ${ }^{2}$ Department of Mathematics Education, Universitas Negeri Medan \\ ${ }^{3}$ Department of Mathematics Education, Universitas Negeri Medan, Medan, Indonesia \\ *Corresponding author: sitihanijahsaragih@gmail.com
}

Received October 05, 2018 Revised November 10, 2018; Accepted November 21, 2018

\begin{abstract}
This study aims to find out (1) validity of learning devices developed through the knisley mathematics learning model; (2) the effectiveness of learning devices developed through the knisley mathematics learning model; (3) the level of ability of students' mathematical understanding by using learning tools developed through the knisley mathematics learning model; (4) the level of students' mathematical disposition by using learning tools developed through the knisley mathematics learning model. Researchers develop learning tools in the form of teacher books, student books, student worksheets (LKS) and learning implementation plans (RPP). Validation of learning devices was carried out by 3 experts and two practitioners and obtained a total average value of validity at intervals of $4 \leq V a<5$ with valid criteria. Mathematics learning devices developed through a technical mathematic model in improving the mathematical understanding and disposition skills of the developed SMP Swasta Tamora 2 students are effective. Based on the results of the ability of mathematical understanding of the test I and trial II, it was found that the average increase in students' mathematical comprehension ability was 4.12. Based on the results of the students 'mathematical disposition questionnaire in trial I and trial II it was obtained that there was an increase in students' mathematical disposition that is equal to 0.61 .
\end{abstract}

Keywords: understanding mathematical ability, 4-D model, learning devices development knisley mathematical learning model

Cite This Article: Siti Hanijah Br. Saragih, Edi Syahputra, Syafari, and Yuli Ragelia Sinaga, "Development of Learning Devices through Knisley Mathematical Learning Model to Improve Mathematical Understanding and Disposition Ability of Class VII SMP Swasta Tamora 2." American Journal of Educational Research, vol. 6, no. 11 (2018): 1522-1530. doi: 10.12691/education-6-11-10.

\section{Introduction}

Learning consists of the process of learning and teaching which is an important core of education. According to Trianto [1] learning is a two-way interaction process between students and educators and between them there is intense and directed communication towards a predetermined target. Learning provides the widest space for students to explore information and knowledge, so learning must be prepared and carried out effectively by involving active students directly.

The success of a teacher as a professional educator can be seen from his success in managing learning. Professional teachers will do thorough preparation before teaching. Suparno [2] suggests that: before the teacher teaches (the preparation stage) a teacher is expected to prepare the material to be taught, prepare teaching aids/practicum to be used, prepare questions and direction to lure active students to learn, learn the state of students, understand weaknesses and strengths of students, as well as learning the students' initial knowledge, all of which will be broken down in the learning tools.

Learning tools facilitate students to actively develop their potential to become a competence. Therefore, the teacher has an obligation to provide a learning experience for students to carry out various activities that allow them to develop their potential to become the competencies established in a plan. According to Trianto "learning devices are devices used in the learning process". Furthermore, according to Suhadi [3] stated that "learning devices are a number of materials, tools, media, instructions and guidelines that will be used in the learning process." From these opinions it can be stated that the learning device is a set of tools or means used by teachers and students in the learning process in class. The set of tools includes the Learning Implementation Plan 
(RPP), Syllabus, Student Worksheet (LKS), books and evaluation tools.

In the 21 st century, education is increasingly important to ensure students have the skills to learn and innovate. One of the abilities that must be developed and become an orientation in $21 \mathrm{st}$ century learning is the ability to understand. In the process of learning mathematics, understanding mathematics is a very important part. Mathematical understanding is an important basis for thinking in solving mathematical problems and problems in everyday life. Developing the ability to understand mathematics, in addition because it is already one of the objectives in the curriculum, this ability is very supportive of other mathematical abilities, namely mathematical communication, mathematical reasoning, mathematical connections, mathematical representations and problem solving.

As stated by Morocco [4], that is, in the twenty-first century there are at least four learning competencies that must be mastered, namely a high understanding ability, critical thinking skills, the ability to collaborate and communicate, and the ability to think creatively. Furthermore related to understanding according to Gollub [5] that "learning with understanding is facilitated when new and existing knowledge is about major concepts and principles of the discipline." Learning with understanding facilitates / facilitates students to associate knowledge old with new knowledge and making it a concept. Mathematical understanding is very important for learning mathematics in a meaningful way, of course the teachers expect that the understanding achieved by students is not limited to understanding that can be connected. According to Ausubel that learning is meaningful if the information that students will learn is arranged in accordance with the cognitive structure of students so that students can relate their new information to their cognitive structure. This means that students can relate the knowledge they have with other conditions so that they learn by understanding.

Many studies have been carried out regarding the ability of mathematical understanding, due to the importance of these abilities. One of them is the research conducted by Pasaribu, Surya and Syahputra. Based on the analysis of Pasaribu, Surya and Syahputra [6] concluded that the ability of mathematical understanding can be improved by using guided discovery learning models.

However, the importance of understanding the above is not yet in accordance with the ability of mathematical understanding that has been achieved by students and this is evident from previous research. Research conducted by Minarni, Napitupulu and Husein [7] found that the ability of students' mathematical understanding in North Sumatra is included in the low category. Observations that have been made by researchers in class VII-1 of Tamora Swasta Junior High School 2 results show that students are only able to make a solution just like the example given by the teacher. When students are given a problem with another form, almost all of them cannot solve the problem. The results obtained from the test are far from expectations. Of the 36 students who took the test only 5 people or $13.8 \%$ of the number of students who were able to solve the given problem. The rest of the students have not been able to solve the problem.
Apart from cognitive abilities, affective abilities that students have also become a goal to develop, namely the development of attitudes. As stated in Permendikbud Number 70 of 2013, one of the characteristics of the 2013 curriculum is to develop attitudes, knowledge and skills and apply them in various situations in schools and communities. Students' attitudes toward mathematics and mathematics learning greatly affect student learning outcomes. A good / positive attitude towards mathematics is usually called a mathematical disposition.

Many studies have been conducted regarding the ability to behave mathematically, due to the need for these abilities to be developed. One of them is research conducted by Syahputra. Based on Syahputra [8] analysis that disposition ability can be improved by using PMRI approach in computer-assisted geometry learning, especially 3-D cabri program. In addition to other studies relating to mathematical dispositions performed by Sibuea, Asmin, Syahputra [9] based on his analysis that the ability of mathematical dispositions can be improved by using problem-based learning models.

However, based on the results of questionnaires given by researchers to 36 students in class VII-1 SMP Swasta Tamora 2, concluded that: (1) $60 \%$ of students were not confident when learning mathematics; (2) $80 \%$ of students have not been persistent and tenacious in doing the tasks of the number of students who are able to solve the given problem. The rest of the students have not been able to solve math problems; (3) $65 \%$ of students do not have curiosity in mathematics; (4) $50 \%$ of students have not appreciated mathematics applications; and (5) 70\% of students have not appreciated the role of mathematics / opinions about mathematics.

Based on the analysis conducted by researchers on the learning devices used in the current SMP Swasta Tamora 2 , there are several weaknesses that need to be corrected. First, the formulation of learning objectives has not applied the principle of audience, behavior, conditon, and degree. Furthermore, the second weakness is the description of learning activities. In the preliminary activity, the teacher does not convey the benefits of the material to be learned in everyday life that can facilitate students to understand the lesson. The third weakness is that it is less detailed and specific in describing the learning activities that will be carried out. The RPP does not use the learning model syntax listed. That is, the application of the chosen learning model has not been done properly. The fourth weakness is that the learning process does not use student worksheets (LKS).

The next weakness is about the textbooks used. Researchers analyzed the book and found that the presentation of material had not led students to build their own knowledge. These weaknesses indicate that the learning tools that are designed and provided are not said to be good. This is also supported by the fact that from interviews with mathematics teachers in grade VII of SMP Swasta Tamora 2 there are several problems, namely: The learning tools developed by the teacher have not been tested for their validity and effectiveness.

For this reason, it is necessary to develop better learning tools that are adapted to the characteristics and conditions of students in SMP Swasta Tamora 2. The tools 
developed will meet valid, effective criteria and meet the applicable curriculum, namely the 2013 curriculum.

\section{Methods}

This study included research development pemebelajaran device that refers to the 4-D models Thiagarajan [10], which consists of four stages, namely the definition phase define, design, develop, disseminate. Learning tools are developed using models problem based learning namely Learning Implementation Plans, Student Activity Sheets, Teacher Books, Student Books, and problem solving ability tests. Model development in this study schematically shown in Figure 1. Explanation of the above scheme, namely.

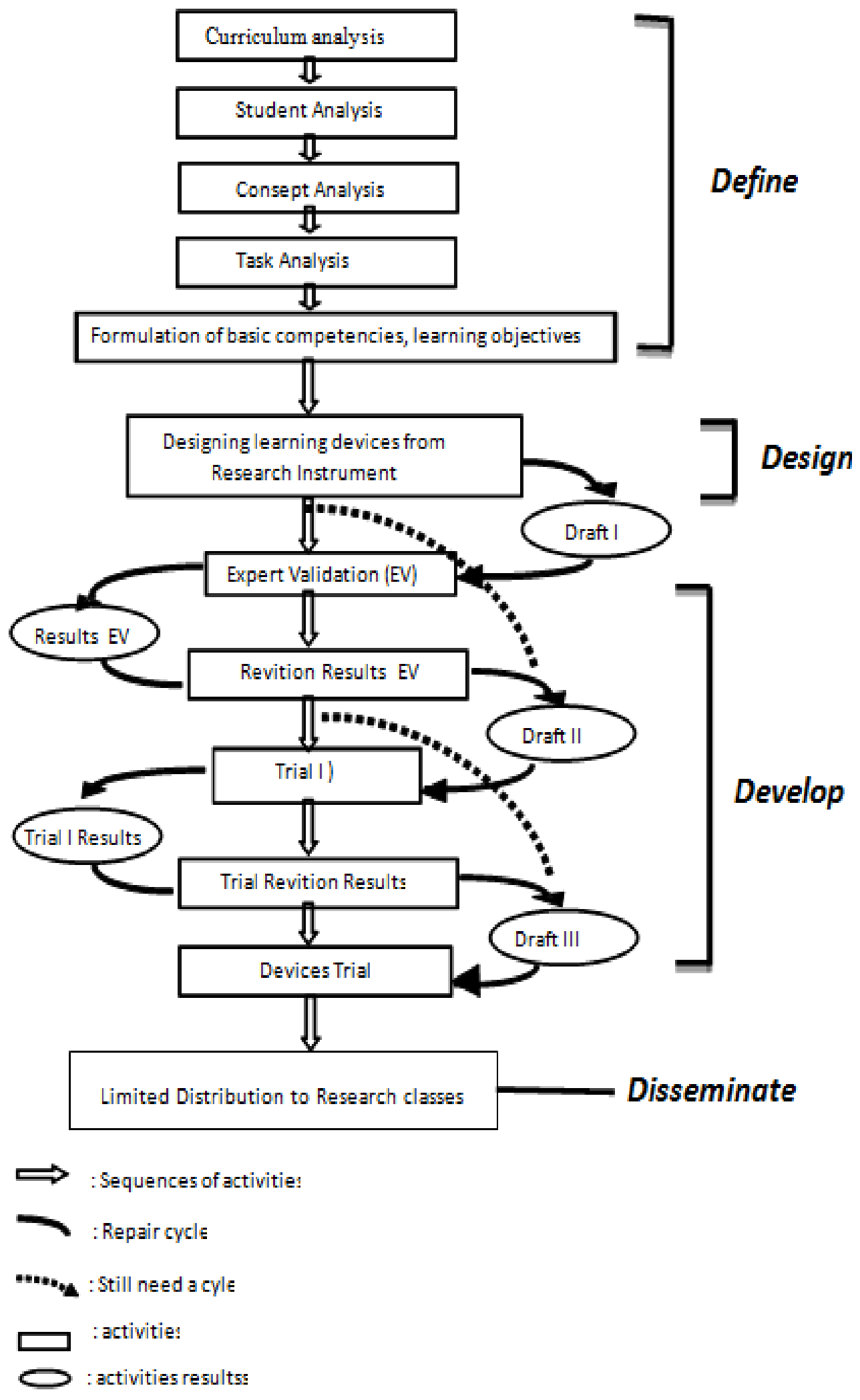

Figure 1. The Scheme for Developing Learning Devices and Task from 4-D Model 


\subsection{Define Phase Consists of}

Analysis of the curriculum that examines the junior math curriculum used in the research area, in order to obtain a description of the learning patterns that are considered suitable. In addition, discussions with partner teachers were conducted to determine the fundamental problems needed in developing the subject matter. Student analysis is examining student characteristics that are in accordance with the design and development of subject matter that has been determined in the curriculum analysis. These characteristics include the ability and level of cognitive development of students.

Concept analysis is identifying, detailing and systematically arranging relevant topics to be taught based on curriculum analysis. Task analysis is to identify the main skills needed in learning according to the Junior Mathematics Curriculum based on concept analysis. The specification of learning objectives is to discuss the results of task analysis and topic analysis into specific learning objectives, which are expressed by behavior.

\subsection{Design Phase Consists of}

Preparation of tests that guide the results of the analysis of the tasks described in the specifications of the learning objectives. In this study the test in question is a test of student learning outcomes, namely comprehension ability tests. To design a test of student learning outcomes, a question grid and reference scoring are made. The scoring used is the Benchmark Reference (PAP) with reason (PAP) oriented to the level of students' ability to the material to be tested, so that the scores obtained reflect the percentage of their ability.

Media selection is determining the right media in presenting learning material. This media selection process is adjusted to the results of the task analysis and analysis of the concepts and characteristics of students.

The initial design is the initial drafting of activities that must be carried out before the trial is carried out. As for the initial design that will involve student activities, namely RPP, Teacher's Book, Student Book, LKS, the ability to test mathematical understanding and students' mathematical dispositions. This initial draft is referred to as Draft I.

\subsection{Develop Phase Consists of}

Validation of experts, namely techniques for obtaining improvement suggestions as well as evaluating the learning devices that have been produced at the design stage. The intended learning tools are all devices that have been developed at the design stage (draft 1). The trial of the research instrument is to produce a good research instrument, in the sense that it is valid and worthy of use in the field

Trial, the field trial, which is a learning tool that has been developed, will be tested on a class which is a place of research that aims to see the effectiveness of learning tools that have been developed that are measured from: (1) Achievement of students classical completeness, (2) active activities of students, (3) positive response of students. From the three conditions above, if one is not fulfilled then the learning tool has not been said to be effective If the results of data analysis are on $p$ In the first trial I produced a learning tool that was not effective and the ability of mathematical understanding and disposition of students had not yet achieved the required completeness, then there would be a trial II.

\subsection{Disseminate Phase}

Disseminate phasenamely the distribution of final devices in partner schools in class VII in quadrilateral material.

\section{Results and Discussion}

\subsection{Description of Stages of Development Learning Tool use Model Learning Mathematics Knisley (MPMK)}

\subsubsection{Define Phase}

Analysis curiculum is based on analysis done that in SMP Swasta Tamora 2 still uses the curriculum SBC, so the learning tools are used, it is still based on the curriculum SBC. Characteristics of students in class VII 2016/2017 academic year that are examined include cognitive development, academic ability, and socioeconomic background. Students of class VII junior high school average age 13-14 years. If it is associated with the stage of cognitive development according to Piaget, then the seventh graders of junior high school are at the stage of formal operational development.

Analysis of these concepts form the quadrilateral concept map as shown in Figure 2.

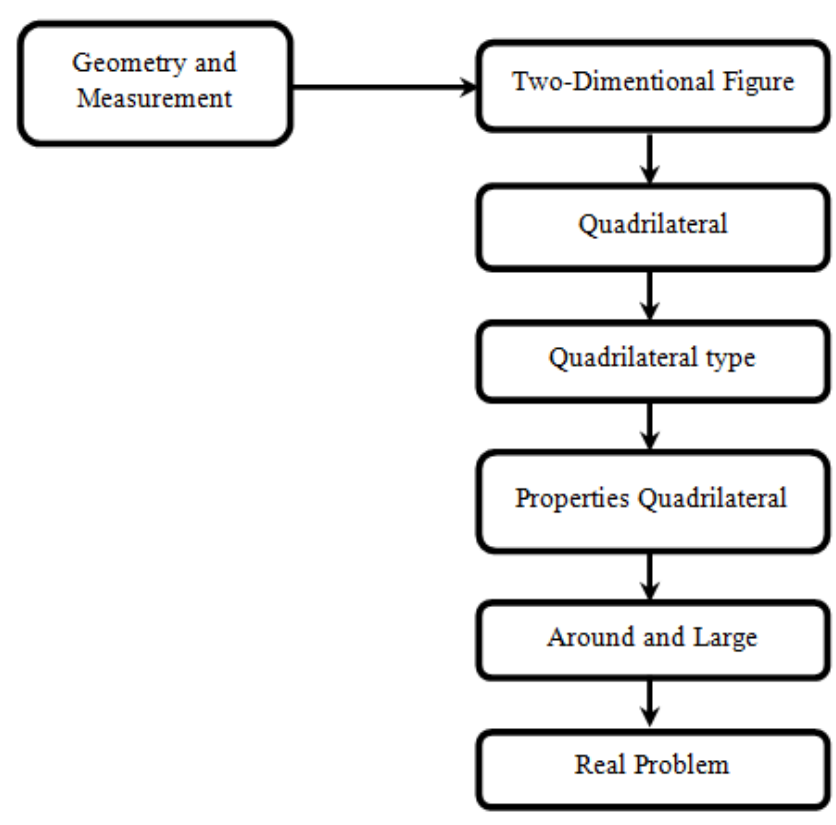

Figure 2. Map Concept Quadrilateral

This analysis is intended to identify key skills required in the learning curriculum quadrilateral corresponding to 2013. Further analysis of academic skills main to be developed in learning. Details of task analysis for quadrilateral material on core competencies observed refer to basic competency indicators. 
Indicators and learning objectives are tailored to the core competencies and basic competencies in accordance with the 2013 curriculum.

After students look at the stories in the textbooks and do question and answer and group discussions it is expected that students are able to solve real problems related to square travel; After students look at the story in the textbook and do question and answer and group discussions, it is expected that students are able to solve the real problems related to the area of the square; After students look at the story in the textbook and do question and answer and group discussion, it is expected that students are able to solve the real problems related to the circumference of the rectangle; After students look at the story in the textbook and do question and answer and group discussions are expected students are able to solve the real problems related to the area of the rectangle; After students look at the story in the textbook and do the question and answer and group discussion it is expected that students are able to solve the real problems associated with trapezoid around; After students look at the story in the textbook and do the question and answer and group discussion it is expected that students can solve the real problems related to the area of the trapezoid; After students look at the story in the textbook and do question and answer and group discussions, it is expected that students are able to solve the real problems associated with traveling around the school; After students look at the story in the textbook and do question and answer and group discussion it is expected that students are able to solve the real problems related to the extent of the gap;

\subsubsection{Design Phase}

\section{1) Tests Preparation of test}

Preparation test in question is a matter of understanding ability tests quadrilateral. Before designing an understanding ability test, the problem lattice is first prepared based on the indicators of comprehension ability and scoring guidelines. Apart from the comprehension ability test, a mathematical disposition scale and a mathematical disposition questionnaire are also based on mathematical disposition indicators. Furthermore, the results of answers from students will be assessed in accordance with the scoring that has been prepared using an evaluation guide that contains the key and guidelines for scoring each item.

\section{2) Media Selection}

Learning media that is needed in the implementation of learning by using learning tools that are developed through the knisley mathematics learning model in grade VII junior high school include: learning implementation plans, teacher books, student books, student worksheets, mathematical understanding ability tests, and mathematical disposition questionnaires.

\section{3) Selection of Format}

Selection of formats for learning devices is adapted to the principles, characteristics of the knisley mathematics learning model. The learning plan includes basic competencies, indicators, teaching materials, prerequisite material, learning media, learning resources, learning models and strategies, and learning scenarios.

4) Preliminary Design

Activities carried out in this step are the initial drafting of quadrilateral learning tools which include Learning Implementation Plans (RPP), Teacher Books, Student Books, Student Worksheets (LKS), students 'mathematical understanding ability tests, and students' mathematical dispositions. this initial draft is referred to as Draft 1 .

\subsubsection{Develop Phase of}

\section{1) Validation Results}

Before the learning tools and research instruments were tested, first the learning tools and research instruments were validated to five validators who included experts in their fields. From the results of the validation, the criteria for learning tools and research instruments developed are "valid" and can be used with minor revisions. Furthermore, the students' mathematical comprehension test ability, tested on the class outside the sample, then tested the validity and reliability.

\section{2) Try Out Results 1}

After the learning device developed has met valid criteria. Then the next learning tool in the form of draft II was tested at the research site, namely the first trial conducted in class VII SMP Swasta Tamora 2 in Tanjung Morawa. The results of the trial 1 data analysis are learning tools that have not been effective, because there are still some indicators of effectiveness that have not been achieved, namely the classical completeness of the ability of mathematical understanding and student activity in the trial 1. Based on the analysis of trial I, it is necessary to revise several components with expectations of learning tools through MPMK can improve students' mathematical understanding and mathematical dispositions. The results of the first trial were used as a reference to improve learning devices. After that a review and revision of the learning device was made, the results of which were called draft III. Draft III will be piloted again in trial II.

\section{3) Trial Results II}

Overall, the results of the trial data analysis II are developed learning tools that have been effective, such as: (1) student activities meet the criteria of the ideal time tolerance that has been set; (2) students respond positively to the MPMK oriented learning components; and (4) the results of the ability to comprehend mathematical comprehension tests meet the criteria for achieving classical student learning completeness. Thus, it is known that the results of trial II are better than trial I. This is due to the MPMK-oriented learning device used in trial II is a revised MPMK-oriented learning device from trial I, so based on the results of trial II it can be concluded that MPMK-oriented learning tools have met the quality of effective learning tools.

\subsubsection{Disseminate Phase}

Development-oriented learning device MPMK reached the final stage in which the mathematics learning device has obtained a positive assessment from the experts and through test development. MPMK-oriented mathematics learning devices in this study were carried out in a limited distribution only to partner schools of material, class / students and time (special distribution). After the final device, the developed MPMK oriented mathematics learning tools are disseminated to be used in quadrilateral material. 


\subsection{Analysis of the Effectiveness of Learning Tools Developed Through MPMK in the Trial I}

The average percentage of student activity time for each category at the first meeting was $28.13 \%$; $16.25 \%$; $26.25 \% ; 26.88 \%$; and $2.50 \%$, each category in the second meeting was $27.50 \%, 17.50 \%, 26.25 \%, 25.00 \%, 3.75 \%$, and the third meeting was $26.21 \%, 19,0 \%, 25.01 \%$, $25.57 \%, 4.21 \%$. The average percentage of student activity time in each activity category for three meetings was $27.83 \%, 17.58 \%, 25.83 \%, 25.81 \%$ and $3.48 \%$. The average percentage of ideal activity time for students to test $\mathrm{I}$ is shown in Table 1 .

Table 1. Percentage of Average Ideal Time Student Activity TryI

\begin{tabular}{|c|c|c|c|c|c|}
\hline \multirow{2}{*}{ Pertemuan } & \multicolumn{5}{|c|}{$\begin{array}{c}\text { Persentase Rata-Rata Pencapaian Waktu Ideal } \\
\text { aktivitas Siswa Untuk Setiap Kategori (\%) }\end{array}$} \\
\cline { 2 - 6 } & 1 & 2 & 3 & 4 & 5 \\
\hline $\mathbf{1}$ & 28,13 & 16,25 & 26,25 & 26,88 & 2,50 \\
\hline $\mathbf{2}$ & 27,50 & 17,50 & 26,25 & 25,00 & 3,75 \\
\hline $\mathbf{3}$ & 26,21 & 19,0 & 25,01 & 25,57 & 4,21 \\
\hline \% Rata-Rata & 27,28 & 17,58 & 25,83 & 25,81 & 3,48 \\
\hline
\end{tabular}

Overall, the average results of the analysis for each aspect of the students' responses were as follows: (1) 95.6\% of students expressed pleasure in the MPMK oriented learning component; (2) $91.2 \%$ of students stated the components and learning activities were still new; (3) 96\% of students expressed interest in participating in mathematics learning in other material such as learning conducted; (4) $96 \%$ of students state the language of the student book, LKS and tests are clear; and (5) 94\% of students expressed interest in the appearance of student books and LKS. The average percentage of the total positive response of students in the first trial was $94.56 \%$. If the results of this analysis are referred to the criteria set out in chapter III, it can be concluded that the student's response to the components and learning activities is positive. Because, more than $80 \%$ of students gave a positive response to the MPMK-oriented learning device component.

One student (4\%) got a $\mathrm{C}$-score, as many as two students $(7 \%)$ got a $\mathrm{C}$ grade, as many as two students $(7 \%)$ got a $\mathrm{C}+$ score, as many as eleven students (39\%) obtained a B-score, as many as nine students (32\%) obtained a B grade, and as many as three students (11\%) obtained a B + score. For more details can be seen in the diagram presented in Table 3.

Table 2. ClassicLevel Ability Mathematical Understanding Ability Test I

\begin{tabular}{|l|c|c|}
\hline \multirow{2}{*}{ Kategori } & \multicolumn{2}{|c|}{ Kemampuan Pemahaman Matematis } \\
\cline { 2 - 3 } & Jumlah siswa & Persentase \\
\hline Tuntas & 23 & $82 \%$ \\
\hline Tidak tuntas & 5 & $18 \%$ \\
\hline Jumlah & 36 & $100 \%$ \\
\hline
\end{tabular}

\subsection{Analysis of Learning Device Effectiveness Developed through MPMK in Trial II}

The average percentage of ideal activity time for students for each category at the first meeting was $26.56 \%$;
$15.63 \% ; 25.78 \% ; 28.91 \%$; and $3.13 \%$, for each of the second meeting categories namely $25.00 \%, 15.63 \%$, $28.13 \%, 28.13 \%$, and 3.13 and at the third meeting, namely $27.69 \%, 19,39 \%, 25.21 \%, 25.16 \%, 2.56 \%$. While the average percentage of ideal time for student activities in each activity category for three meetings was $26.41 \%$, $16.88 \%, 26.37 \%, 27.4 \%$, and $2.94 \%$. The average percentage of ideal activity time for students to try out I is shown in Table 3.

Table 3. Percentage of Average Ideal Time Student Activity Trial II

\begin{tabular}{|c|c|c|c|c|c|}
\hline \multirow{2}{*}{ Pertemuan } & \multicolumn{4}{|c|}{$\begin{array}{c}\text { Persentase Rata-Rata Pencapaian Waktu Ideal } \\
\text { aktivitas Siswa Untuk Setiap Kategori (\%) }\end{array}$} \\
\cline { 2 - 6 } & $\mathbf{1}$ & $\mathbf{2}$ & $\mathbf{3}$ & $\mathbf{4}$ & $\mathbf{5}$ \\
\hline $\mathbf{1}$ & 26,56 & 15,63 & 25,78 & 28,91 & 3,13 \\
\hline $\mathbf{2}$ & 25,00 & 15,63 & 28,13 & 28,13 & 3,13 \\
\hline $\mathbf{3}$ & 27,69 & 19,39 & 25,21 & 25,16 & 2,56 \\
\hline \% Rata-Rata & 26,41 & 16,88 & 26,37 & 27,4 & 2,94 \\
\hline
\end{tabular}

The above description shows that when learning, students are active and have high enthusiasm in participating in learning using learning tools developed through MPMK. Students do more activities related to learning than things that are not relevant to learning. This has made the atmosphere conducive, as expressed by Wasriono, Syahputra, Surya [11] that student activities in the learning process will lead to interaction between the teacher and students or fellow students, resulting in a conducive classroom atmosphere, and each student maximally. This is in line with the research conducted by Mulyana [12] that one of the advantages of a knisley mathematics learning model is that it can increase students' enthusiasm for active thinking so as to create a conducive atmosphere.

Overall, the average analysis results for each aspect of student response are as follows: (1) $96.4 \%$ of students expressed pleasure in the MPMK-oriented learning components; (2) $94.4 \%$ of students stated that components and learning activities were still new; (3) $100 \%$ of students stated interested in taking mathematics lessons in other material such as learning that is done; (4) $98.6 \%$ of students stated the language in the student book, LKS and tests were clear; and (5) $96 \%$ of students expressed interest in the appearance of student books and LKS. The average percentage of the total positive response of students in the first trial was $97 \%$. If the results of this analysis are referred to the criteria set out in chapter III, it can be concluded that the student's response to the components and learning activities is positive. Because, more than $80 \%$ of students gave a positive response to the components of learning tools developed through MPMK. this is referred to the criteria set out in chapter III, it can be concluded that the student's response to the components and learning activities is positive. Because, more than $80 \%$ of students gave a positive response to the MPMK-oriented learning component of the device. Based on the exposure of research results and supporting research, it can be concluded that the learning tools developed through MPMK have met the effective criteria in terms of student activities.

One student (7\%) obtained an A- score, as many as eight students $(28.5 \%)$ got a $\mathrm{B}+$ score, as many as fourteen students $(50 \%)$ obtained a B score, as many as 
three students (11\%) obtained a B- score, and as many as one student $(3.5 \%)$ obtained a $\mathrm{C}+$ score. Classical completeness level of students' mathematical comprehension ability in trial II is shown in Table 4.

Table 4. Classic Level Ability Mathematical Understanding in Trial II

\begin{tabular}{|c|c|c|}
\hline \multirow{2}{*}{ Kategori } & \multicolumn{2}{|c|}{ Kemampuan Pemahaman Matematik } \\
\cline { 2 - 3 } & Jumlah siswa & Persentase \\
\hline Tuntas & 27 & $96,5 \%$ \\
\hline Tidak tuntas & 1 & $3,5 \%$ \\
\hline Jumlah & 28 & $100 \%$ \\
\hline
\end{tabular}

The results of the study in this study indicate that the mastery of classical student learning using developed learning tools meets the criteria for effectiveness. This is because by applying learning tools developed through MPMK, students actively seek, students learn with an understanding of a concept, students develop their own knowledge, and make conclusions from knowledge found with guidance and guidance from the teacher. as expressed by Pasaribu, Surya, Syahputra [6] in his research that mathematical understanding is the ability to explain a situation or an action.

\subsection{Improvement of Students' Mathematical Understanding Ability Taught Using MPMK Oriented Learning Tools}

The results of the analysis of students' mathematical comprehension skills in trials I and II showed that the average ability of mathematical comprehension in the test results of students' mathematical comprehension ability test I was 66.25 increased to 81.25 in trial II. This is consistent with the data analysis of the improvement of problem solving abilities in chapter III, namely an increase in mathematical understanding seen from the average results of the mathematical comprehension ability test of trials I and II, thus it is known that there is an increase in the average value of students' mathematical comprehension ability of 15 Increasing the ability of students' mathematical understanding in trials I and II is shown in Table 5.

Table 5. Mathematical Understanding Ability Test Results

\begin{tabular}{|c|c|c|}
\hline Keterangan & $\begin{array}{c}\text { Tes Kemampuan } \\
\text { Pemahaman } \\
\text { Matematis Uji Coba I }\end{array}$ & $\begin{array}{c}\text { Tes Kemampuan } \\
\text { Pemahaman Matematis } \\
\text { Uji Coba II }\end{array}$ \\
\hline Nilai Tertinggi & 82,5 & 97,5 \\
\hline Nilai Terendah & 50 & 65 \\
\hline Rata-rata & 66,25 & 81,25 \\
\hline
\end{tabular}

One of the objectives obtained from the development of learning tools in this study is to increase students' mathematical understanding ability. Mathematical understanding is closely related to the learning that is proposed by Ausubel. Meaningful learning is a learning process by linking the structure of understanding that students already have. This means that there is a connection between old knowledge and new knowledge. This is evidenced in the research conducted by Hasibuan, Surya, Syahputra [13] concluding that the ability of mathematical understanding can be seen from the translation indicator which is able to associate old knowledge with new knowledge. In conclusion the ability of mathematical understanding students get $85.4 \%$ with good categories.

According to Kolb [14] understanding-based learning is an overall brain activity, so that learning is effective it must encourage students to do all learning styles in one cycle. The cycle corresponds to the activities applied to MPMK. Concrete-reflective learning style, corresponds to student activities as allegorizer, cognitive-active learning style, corresponds to student activity as an integrator, abstract-reflective learning style corresponds to student activity as an analyst, and abstract-active learning style corresponds to student activity as syntax . Based on this, it can be concluded that MPMK is very suitable for developing students' mathematical understanding abilities. Based on the results of an analysis of the increasing ability of students' mathematical understanding in the I and II trials in this study showed that the average ability of mathematical understanding on the results of mathematical comprehension ability tests trial I was 66.25 increased to 81.25 in trial II. Thus, there is an increase in the average value of students 'mathematical comprehension ability by 15 .

\subsection{Increasing Students' Mathematical Disposition Taught Using MPMK Oriented Learning Tools}

Based on the results of the students 'mathematical disposition questionnaire data analysis in the first trial and trial II shows that the students' mathematical disposition increases (better), ie the average questionnaire in trial 1 was 2.83 while in the second trial was 2.98 and increased by 0.61 . Increased mathematical disposition can be seen from the average results of the mathematical disposition questionnaire filled by students. Increased mathematical disposition is also seen in each aspect of mathematical disposition, namely: (1) Confidence in solving mathematical problems, has increased by 0.18 ; (2) Perseverance and perseverance in solving mathematical problems, has increased by 0.07 ; (3) Having interest and curiosity in working on mathematics, has increased by 0.24 ; and (4) Assessing the application of mathematics in other fields in daily life, has increased by 0.12 .

Table 6. Average Mathematical Disposition Score of Students in Test I and Trial II

\begin{tabular}{|c|c|c|c|c|}
\hline \multirow{2}{*}{ No. } & \multirow{2}{*}{$\begin{array}{c}\text { Mathematical Disposition } \\
\text { Aspects }\end{array}$} & \multicolumn{2}{|c|}{$\begin{array}{l}\text { Average Score per } \\
\text { Aspect }\end{array}$} & \multirow{2}{*}{$\begin{array}{l}\text { Average } \\
\text { Increased }\end{array}$} \\
\hline & & Trial 1 & Trial 2 & \\
\hline 1. & $\begin{array}{l}\text { Confidence in solving } \\
\text { mathematical problems }\end{array}$ & 2.78 & 2.96 & 0.18 \\
\hline 2. & $\begin{array}{l}\text { Diligent and persistent in } \\
\text { solving mathematical problems }\end{array}$ & 2.78 & 2,85 & 0.07 \\
\hline 3. & $\begin{array}{l}\text { Having interest and curiosity } \\
\text { in doing mathematics }\end{array}$ & 2.77 & 3.01 & 0.24 \\
\hline 4. & $\begin{array}{l}\text { Assessing the application of } \\
\text { mathematics in other fields in } \\
\text { daily life }\end{array}$ & 3.03 & 3.15 & 0.12 \\
\hline \multicolumn{2}{|r|}{ Total average of all aspects } & 2.83 & 2.98 & \\
\hline \multicolumn{2}{|r|}{ Total Increase in All Aspects } & \multicolumn{3}{|c|}{0.61} \\
\hline
\end{tabular}


The highest indicator of students' mathematical disposition is an indicator of interest and curiosity in doing mathematics. This is in line with the research by Syahputra [8] in his research revealing that the highest indicator of students' mathematical disposition is "cooperative attitude" and "curiosity". Things that make students' mathematical dispositions increase after using the learning tools used is because learning with knisley mathematics learning models is a new thing for students. The same thing was also revealed in the Sibuea, Asmin, Syahputra [9] study of the research that makes the mathematical dispositions of experimental class students better than the mathematical dispositions of control class students, one of which is because problem-based learning given to experimental class students is new thing. In addition, students who have positive mathematical dispositions will tend to ask questions and solve problems they have just discovered. This is supported by research conducted by Safitri, Surya, Syahputra, Simbolon [15] students who already have a high mathematical disposition will tend to continuously reflect in the way they ask and answer questions that are asked about new problems and approaches they found. As evidence of mathematical dispositions can be seen shown in students' written exercises such as home assignments, project development and journals or presentations by students can also provide valuable information regarding the disposition of mathematics students. Like individual or group presentation projects regarding problem solutions or proof of theorems can be used as evidence of how much students need to be diligent and steadfast in doing their tasks and not trying alternative methods to solve problems.

\section{Conclusion}

Based on the results of the analysis and discussion in this study, some conclusions are stated as follows:

1. Mathematics learning devices developed through the krisley mathematics learning model are valid in improving the ability of mathematical understanding and mathematical disposition of students with validity levels at intervals: $4 \leq \mathrm{Va}<5$ with Valid criteria and slight revisions;

2. Development of learning tools developed through the Knisley Mathematics Learning Model (MPMK) is effectively used to improve the ability of mathematical understanding and mathematical dispositions student. This was obtained from the results of trial I and trial II where the development of learning tools developed through MPMK had achieved effective criteria: (1) student activities during learning activities met the criteria for the ideal time tolerance set; (2) positive student response to the components of learning devices and learning activities developed reached more than $80 \%$; and (3) classical student learning completeness has been achieved $96.5 \%$ in trial II;

3. The ability of students' mathematical understanding using learning tools developed through MPMK in quadrilateral material increased by $15 \%$ in the second trial with an average of 81.25.
4. The attitude of students' mathematical disposition using learning tools developed through MPMK reached an average of 2.83 in test I and increased to 2.98 in the trial II. In addition, the average of each indicator of students' mathematical disposition increases from trial I to trial II.

\section{Acknowledgements}

On this occasion the author expressed his deepest gratitude to his beloved Father and Mother (Mr. Buyung Saragih and Mrs. Rusmiati), sisters (Yunarse, Wartini Br. Saragih, Ramayanti Br. Saragih, and Jamilah Br. Saragih) and all beloved family who always pray for, give full and motivating support in completing this writing.

\section{References}

[1] Trianto. 2013. Designing an Innovative Learning Model The Progressive Concept of Platform and Implementation on KTSP. Jakarta: Kencana Prenada Media Group.

[2] Suparno, P. 2002. Jean Piaget's Cognitive Development Theory. Kanisus: Yogyakarta.

[3] Suhadi. 2007. Instructions for Learning Devices. Surakarta: Muhammadyah University.

[4] Morocco, CC, et al. (2008) Supported Literacy for Adolescents: Transforming Teaching and Content Learning for The TwentyFirst Century. San Francisco: Jossey-Bass A Wiley Imprint.

[5] Gollub, Jerry P., Bertenthal, Meryl W. 2002. Learning and Understanding: Improving Advanced Study of Mathematics and Science in US High Schools. Washington, DC: National Academy Press.

[6] Pasaribu, Endi Zunaedy., Surya, Edy., Syahputra, Edi. 2016. Improvement of Students' Understanding and Mathematical Disposition Ability through Guided Discovery Learning Models in MTSN 1 Padang Sidimpuan. Paradikma Journal. 9 (2): 11-19.

[7] Minarni, Ani., Napitupulu, EE and Husein, R. 2016. Mathematical Understanding and Representation Ability of Public Junior High School in North Sumatra. Journal on Mathematic Education. 7 (1): 43-56.

[8] Syahputra, Edi. 2011. Increasing Spatial Ability and Mathematical Disposition of Middle School Students with PMRI Approach to Computer Assisted Geometry Learning. Bandung: Indonesian University of Education.

[9] Sibuea, Fitri, Larasati, Mustika., Asmin., Syahputra, Edi. 2015. Improvement of Communication and Mathematical Disposition Ability of Students of Tamansiswa Sukadamai Vocational School, Asahan Regency through Problem Based Learning Model. Paradikma Journal. 8 (3): 70-83.

[10] Thiagarajan, S., Semmel, DS \& Semmel, MI (1974). 'Instructional Development for Teachers of Expectional Children Minneapolis' Training. Minnesota: Leadership Training Institute / Special Education, University of Minnesota.

[11] Wasriono., Syahputra, Edi., Surya, Edy. 2015. Development of Autograph Assisted Learning Devices to Improve Understanding of Mathematical Concepts of Vocational Students through Guided Discovery Models. Paradikma Journal.8 (3): 52-6.

[12] Mulyana, Endang.2014. Influence of Knisley Mathematical Learning Models on Increased Mathematical Understanding and Disposition of High School Students in Natural Sciences Program.Journal of Teaching and Learning MIPA. 17 (1): 8-16.

[13] Hasibuan, Afifah, Zahrah, Oktaviani., Surya, Edi., Syahputra, Edi. 2017. The Application of CTL to Improve Students' Understanding Concept Ability by Matflash Graphic Media Assistance. International Journal of Advance Research and Innovative Ideas in Education. Paradikma Journal. 3 (2): 32223230 .

[14] Kolb, DA 1984. Experiential Learning: Experience as the Source of Learning and Development. New Jersey: Englewood Cliffs. 
[15] Safitri, Adek., Surya, Edy., Syahputra, Edi., Simbolon , Maruli. 2017. Impact of Indonesian Realistic Mathematics Approach to Students Mathematic Disposition on Chapter Two Composition
Function and Invers Fungtion in Grade XI IA-1 SMA Negeri 4 Padangsidimpuan. International Journal of Novel Research in Education and Learning. 4 (2): 93-100. 